\title{
SELECTING AND MODIFYING METHODS OF MANUAL MUSCLE TESTING FOR CLASSIFICATION IN PARALYMPIC SPORT
}

\author{
Sean M. Tweedy ${ }^{*}$ Gavin Williams ${ }^{* *}$,John Bourke*** \\ * The University of Queensland, School of Human Movement Studies, Australia \\ ** Physiotherapy Department, Epworth Hospital, Melbourne, Australia \\ *** Department of Orthopedic Surgery, St John of God Health Care, Australia
}

\begin{abstract}
Many Paralympic sports classification systems use unspecified manual muscle testing (MMT) methods to assess impairment of muscle strength. This is a potential source of inconsistency in classification, and could be eliminated by nominating a single, published set of MMT methods. Additionally, four modifications can enhance the validity, reliability and utility of conventional MMT methods for classification: 1) limiting assessment to movements that are important to performance in the sport concerned; 2) specifying a single preferred technique for assessment of movement strength; 3 ) changing the reference range of movement from normal anatomical range to the maximum range of movement required in sport; and 4) adjusting testing techniques so that they are relevant for the sport. This brief communication may improve classification in established sports, and provide guidance for emerging sports that are developing classification systems.
\end{abstract}

KEYWORDS: muscle strength, strength assessment Paralympic, sport, impairment, disability

\section{INTRODUCTION}

The recently published IPC Position Stand on classification in Paralympic sport states that the purpose of Paralympic systems of classification is to promote participation in sport by people with disabilities by minimizing the impact of impairment on the outcome of competition (Tweedy \& Vanlandewijck, 2010), where impairment (World Health Organization, 2001) is any problem with body structure or body function (e.g., paresis, hypertonia or decreased range of movement). The Position Stand (Tweedy \& Vanlandewijck, 2010) goes on to state that, in order to minimize the impact of impairment on the outcome of competition, each classification system should:

- Describe eligibility criteria in terms of:

- type of impairment; and

- severity of impairment;

- Describe methods for classifying eligible impairments according to the extent of activity limitation they cause, where an activity limitation (World Health
Organization, 2001) is difficulty executing an activity (e.g., propelling a wheelchair, running, throwing or jumping).

Classification systems that achieve this purpose will help to ensure that competitive success within a class is determined by factors such as skill, determination and training and will reduce the chances that an athlete will be precluded from success because they have an impairment that causes more activity limitation than their competitors (Tweedy, 2002; Tweedy \& Vanlandewijck, 2010).

In many current systems of classification, a multiprofessional team estimates the extent of activity limitation resulting from impairment through assessment of four principal areas: a) impairments of structure and function (e.g., muscle strength, reflexes, hypertonicity, range of movement); b) activity limitation experienced in motor tasks that are novel, yet biomechanically related/similar (i.e., motor tasks unlikely to have been practiced by an 
athlete in the sport concerned); c) assessment of activity limitation in sport specific motor tasks (i.e., drills and movements fundamental to the sport of the athlete); d) assessment of factors other than impairment that will affect activity limitation (e.g., the equipment used by the athlete, their level of training, age and anthropometry) (Tweedy, 2002). Results from all four areas of assessment are taken into account and a class is assigned when the panel reaches consensus. To minimize potential sources of intra- and inter-panel variability in assigning classifications, standardization of assessment methods is vital.

There are 20 Summer Paralympic sports and 14 of these use manual muscle testing (MMT) methods for assessing impairment of muscle strength (see Table 1). MMT methods, in which the strength of a muscle, or group of muscles, is assigned a grade according to its capacity to overcome gravity and / or manual resistance, were first described in 1912 (Wright, 1912)
These original methods have been adapted and modified since they were first published and current publications that describe methods for MMT include, but are not limited to, those authored by Clarkson (Clarkson, 2000), Cutter and Kevorkian (Cutter \& Kevorkian, 1999), Hislop and Montgomery (Hislop \& Montgomery, 2007), Guarantors of Brain (Guarantors of Brain, 2000) and Kendall (Kendall, 2005). Moreover, a number of these publications have several editions for example the Hislop and Montgomery publication is in its $8^{\text {th }}$ edition, Guarantor's of Brain in its $4^{\text {th }}$ and Kendall and McCreary in its $5^{\text {th }}$. Unfortunately, of the 14 classification systems that incorporate MMT methods, only five - Athletics, Equestrian, Wheelchair Rugby, Rowing and Swimming - specify which of the published methods classifiers should employ (see Table 1). Consequently, in nine of the 14 Paralympic sports that employ MMT, it is quite likely that classifiers use various MMT methods, depending on their original professional training.

Table 1: Summer Paralympic sports which explicitly incorporate the use of manual muscle testing in the classification process (i.e., to determine eligibility or assign class).

\begin{tabular}{|l|l|l|}
\hline Sport & $\begin{array}{l}\text { Uses manual muscle } \\
\text { testing? }\end{array}$ & Manual Muscle Testing method used \\
\hline Archery & Yes & Unspecified \\
\hline Athletics & Yes & Daniels and Worthingham (2002) \\
\hline Boccia & $\mathrm{No}^{1}$ & N/A \\
\hline Cycling & Yes & Unspecified \\
\hline Equestrian & Yes $^{2}$ & Daniels and Worthingham (1986) \\
\hline Football 5-a-Side & $\mathrm{No}^{2}$ & N/A \\
\hline Football 7-a-Side & $\mathrm{No}^{1}$ & N/A \\
\hline Goalball & $\mathrm{No}^{2}$ & N/A \\
\hline Judo & $\mathrm{No}^{2}$ & N/A \\
\hline Powerlifting & Yes & Unspecified \\
\hline Rowing & Yes & Daniels and Worthingham (2007) \\
\hline Sailing & Yes & Unspecified \\
\hline Shooting & Yes & Unspecified \\
\hline Swimming & Yes & Medical Research Council \\
\hline Table Tennis & Yes & Unspecified \\
\hline Volleyball (Sitting) & Yes & Unspecified \\
\hline Wheelchair Basketball & Yes & Unspecified \\
\hline Wheelchair Fencing & Yes & Unspecified \\
\hline Wheelchair Rugby & Yes & Daniels and Worthingham (2007) \\
\hline Wheelchair Tennis & Yes & Unspecified \\
\hline
\end{tabular}

${ }^{1}$ Classifies hypertonia, ataxia and athetosis;

${ }^{2}$ Classifies vision impairment only 
The purpose of this paper is threefold: to illustrate that specification of the MMT methods used is an important means of minimizing potential sources of variation in classification outcome; to evaluate which of the MMT methods currently utilized in Paralympic classification is better suited to the purposes of Paralympic classification; and to describe how MMT methods can be modified so that their validity, reliability and utility in Paralympic sports classification can be optimized.

\section{The importance of specifying MMT methods}

While a range of MMT methods have been published, Paralympic classification systems have demonstrated a clear preference for just two: the Daniels and Worthingham (D\&W) methods (Daniels and Worthingham, 1986; Hislop and Montgomery, 2007; Hislop and Montgomery, 2002) and Aids to the Examination of the Peripheral Nervous system (Guarantors of Brain, 2000) which are commonly referred to as the Medical Research Council (MRC) methods. The classification systems which utilize the respective manual muscle testing methods are presented in Table 1. Consequently, the scope of this paper has been limited to consideration of the D\&W methods ( $7^{\text {th }}$ edition, 2002) and MRC methods ( $4^{\text {th }}$ edition, 2000).

Fundamentally, the D\&W and MRC methods are quite similar. Both use similar six point scales to grade muscle strength (see Table 1) and in both scales, a grade of zero indicates no voluntary muscle contraction and five indicates normal muscle strength. Moreover, both describe muscle grades in relation to movement against gravity and movement against manual resistance. However the D\&W scale differs from the MRC in that it also uses range of movement as a descriptor while the MRC does not. Differences in recommended testing position and stabilization techniques also exist. These differences are partly attributable to the slight conceptual differences between the methods - the D\&W methods generally assess muscle actions (e.g., wrist extension) while the MRC methods assess individual muscles (e.g., Extensor Carpi Ulnaris and Extensor Carpi Radialis Longus).

The differences between the D\&W and MRC methods may lead to quite different assessment outcomes. For example, using the D\&W methods, ankle plantar flexors can be tested as a single muscular complex. The person is positioned in single leg standing and a grade of five is assigned if 20 heel rises can be performed through full range of movement; a grade of two is assigned if, while positioned in prone, full available range can be completed and held against maximum resistance (Hislop \& Montgomery, 2002). In contrast, the MRC methods require that the Gastrocnemius and Soleus are tested and scored separately while the person is lying supine (no tests are conducted in standing). Gastrocnemius is tested with hip and knee extended and Soleus with hip and knee flexed. Both muscles are graded five if the person can overcome strong manual resistance from the examiner (Guarantors of Brain, 2000). Consequently a Gastrocnemius and a Soleus muscle may each be assigned a grade of five using the MRC methods, but the same muscles may collectively be assigned a grade of 2 when assessed using the D\&W methods.

Manual muscle test scores can have a profound impact on classification outcomes. For instance, people with reduced muscle power in the lower limbs (e.g., from spinal cord injury, polio, peripheral nerve damage etc) are eligible for a range of Paralympic sports - powerlifting, athletics, swimming and equestrian and a number of others providing they have lost a specified number of muscle grade points (e.g., to be eligible for powerlifting, athletes must lose at least 10 points in the lower limbs). Consider the case of a person with otherwise normal muscle strength but grade 3 hamstring strength and bilateral plantarflexion weakness which permits them to overcome strong manual resistance in lying but which does not permit 
them to raise their heel off the floor in single leg standing. Such a person would be deemed eligible for powerlifting if assessed using D\&W methods, having lost 10 muscle grade points (two at each of the hamstrings and three at each of the ankle plantar flexors). However, if assessed using MRC methods, the same athlete would be deemed ineligible, having lost only four points (two at each of the hamstrings; plantar flexors would be scored as grade 5).

In the same way, the methods of manual muscle testing used by a classification team can alter the outcome of an assessment and alter the class a person is assigned. The class assigned can profoundly influence the degree of success a given athlete is likely to achieve, potentially impacting upon a person's selfperception and self-esteem, their peer and community recognition, as well as their access to sponsorship and other financial rewards. In short, classification outcomes have a profound impact on participation and competition in Paralympic sport and therefore it is critical that potential sources of inconsistency are minimized. By specifying the MMT methods they employ, sports classification systems can eliminate a potential source of inconsistency.

\section{MRC or D\&W methods in classification ?}

Studies indicate that acceptable levels of inter-examiner reliability are difficult to achieve, regardless of the MMT methods used (Escolar et al., 2001; Florence et al., 1992; Frese et al., 1987; Hislop and Montgomery, 2002; Lawson and Calderon, 1997). Despite this limitation, MMT methods remain an integral component of Paralympic sports classification. This is principally because they are widely practiced internationally, require little equipment and are easy to administer important qualities in the context of increasing access to classification and promoting participation in Paralympic sport. Although inter-rater reliability tends to be low, several factors have been shown to enhance MMT reliability, including increased examiner experience, increased examiner training time and strict adherence to testing methods (e.g., positioning, stabilization and application of manual resistance) (Escolar, et al., 2001; Hislop and Montgomery, 2002). These factors are particularly important given the global nature of Paralympic sports and the resultant diversity in culture, language and professional and educational backgrounds of classifiers. Consequently, an important means of reducing inter-examiner variability and enhancing reliability would be to preferentially select a MMT method which incorporated detailed guidelines for administration.

One of the principal differences between the D\&W and MRC methods lies in the level of detail provided in the respective guidelines for administration - the MRC methods are brief and simple while the D\&W methods are more comprehensive. Evaluation of both sets of guidelines indicate that the additional information provided in the D\&W methods will serve to enhance reliability in classification and that they should therefore be preferred.

More specifically, three important guidelines are included in the $\mathrm{D} \& \mathrm{~W}$ methods but are omitted from the MRC methods. The first indicates how to grade a muscle action that can overcome gravity, but does not act through full available range of movement $(\mathrm{ROM})$ - the D\&W methods indicate that the grade assigned must be 2 , while the MRC methods do not specify whether such a muscle should be assigned a grade 2 or grade 3. The second advantage of the D\&W guidelines is that they indicate how to position and stabilize patients for testing all grades of muscle (including for elimination of gravity), a feature which aids standardization of test administration. In contrast, the MRC methods describe only one position per muscle test, some of which are in gravity assisted positions and some of which are against gravity. Finally, the MRC methods do not specify how manual resistance should be applied to a contracting muscle, while the D\&W specifies that the break test is the 
preferred method - at the end of available range the patient is asked to hold the part and not allow the examiner to "break" (i.e., move the part from) that position. This element of standardization is likely to enhance the interpanel reliability of MMT.

\section{Modifying the D\&W methods for Paralympic sports classification}

A sports classification system that employs the D\&W methods should nominate which of the published versions it is based upon and adhere to the methods described in that version wherever practical and justified. However there are four areas in which the D\&W methods may be modified in order to improve their validity, reliability and utility in a given Paralympic sports classification system. It is critical to note that The remainder of this paper provides worked examples of how the proposed modifications can be applied in the sport of track athletics. It should be noted that, although the four areas of modification have been written specifically for the D\&W methods, the principles underpinning them can be applied to the modification of other published MMT methods so that their suitability for sports classification is enhanced.

\section{Modification 1: Selection of movements to be} assessed

The D\&W methods assess a comprehensive array of muscle actions. However, for the purposes of classification, only those movements that are judged to be sufficiently important to sports performance should evaluated. For example, while D\&W methods include techniques for evaluating the movement strength of internal and external hip rotation, these movements make a negligible contribution to forward running, as evidenced by their omission from studies that describe activation patterns for the muscles used in running (Mann \& Hagy, 1980; Novacheck, 1998). Therefore internal and external hip rotators do not need to be assessed for the purposes of running classification. Wherever possible, the selection of movements for testing should be based on normal biomechanics/ biomechanical data for each specific activity. By eliminating manual muscle tests which are not relevant to sports performance, the process of assessment can be streamlined and the utility of the system improved.

Modification 2: Specification of movement testing technique

In several instances $\mathrm{D} \& \mathrm{~W}$ methods describe more than one technique for testing the strength of a movement. For instance, two techniques are described for assessing hip extension. Both are in prone, one with knee extended (the movement effected by both the hamstrings and gluteus maximus) and the other with the knee flexed (the movement effected by gluteus maximus in isolation). By specifying a single technique, reliability in classification can be enhanced. Biomechanical analysis of the relevant sport can provide a rationale for technique selection and enhance validity. For example, during running the knee is close to full extension when the hip is extending (Mann \& Hagy, 1980; Novacheck, 1998) and therefore assessment of hip extension strength with the knee extended would appear to have the greatest validity for classification in running.

Modification 3: Changing the reference ROM The reference ROM for the D\&W scale is normal anatomical range - that is, the words "full range of movement" used in the criteria for grading (see Table 1) mean full normal, anatomical range of movement. For example, normal anatomical range of movement for hip flexion is $120^{\circ}$ and hip flexion is assessed as grade five if the hip can be flexed to $120^{\circ}$ and maximum force can be resisted at the end point (Hislop and Montgomery, 2002).

In the event a person is assessed as having passive ROM of $120^{\circ}$ at the hip but is only able to flex to $100^{\circ}$ against gravity, the $\mathrm{D} \& \mathrm{~W}$ methods indicate the movement strength must receive a grade of two, because they cannot complete the available range of movement against gravity (Hislop and Montgomery, 2002). However, the maximum range of hip 
flexion required for running - including elite level sprinting - is only $90^{\circ}$ (Mann \& Hagy, 1980; Novacheck, 1998) and assignment of a grade 2 is unlikely to be a valid reflection of the activity limitation such a person would experience in running.

In order to address this issue for the sport of track athletics, the reference range should be changed from "normal anatomical range" to "the maximum range of movement required in running". Moreover, the break test would usually be applied at the end of the ROM required for running. Therefore, a person with

$100^{0}$ hip flexion against gravity would receive a grade of three to five, depending on the amount of force that could be resisted at $90^{\circ}$ hip flexion. This method is likely to provide a more valid indication of the activity limitation such a person would experience in running.

Wherever possible, Paralympic sports that adjust the reference range of movement in this fashion should base adjustments on a thorough biomechanical analysis of the published scientific literature. A worked example of this method for adjusting the reference range of movement for running is presented in Table 2. The table indicates that, in most instances the maximum ROM required for running is substantially less than normal anatomical range.

Table 2: Two manual muscle testing scales - the MRC scale (Guarantors of Brain, 2000) and the Daniels and Worthingham scale (H. J. Hislop \& Montgomery, 2002).

\begin{tabular}{|c|c|c|}
\hline $\begin{array}{c}\text { Numerical } \\
\text { Score }\end{array}$ & MRC Scale & $\begin{array}{l}\text { Daniels and Worthingham Scale } \\
\text { (summary) }\end{array}$ \\
\hline 0 & No contraction & No contraction \\
\hline 1 & $\begin{array}{l}\text { Flicker or trace } \\
\text { contraction }\end{array}$ & Flicker or trace activity. \\
\hline 2 & $\begin{array}{l}\text { Active movement with } \\
\text { gravity eliminated }\end{array}$ & $\begin{array}{l}\text { Muscle can move joint through full range of } \\
\text { movement in a position that minimizes gravity. }\end{array}$ \\
\hline 3 & $\begin{array}{l}\text { Active movement } \\
\text { against gravity }\end{array}$ & $\begin{array}{l}\text { Muscle can complete a full range of movement } \\
\text { against only the resistance of gravity, but } \\
\text { application of resistance causes movement to } \\
\text { break. }\end{array}$ \\
\hline 4 & $\begin{array}{l}\text { Active movement } \\
\text { against gravity and } \\
\text { resistance }\end{array}$ & $\begin{array}{l}\text { Muscle goes through full range of movement and } \\
\text { can tolerate strong resistance without breaking in } \\
\text { the end position. When maximum resistance is } \\
\text { applied there is a clear break. }\end{array}$ \\
\hline 5 & Normal power & $\begin{array}{l}\text { Normal strength - examiner cannot break the finish } \\
\text { position at end of tested range (e.g., test elbow } \\
\text { flexors by going to full flexion and trying to pull } \\
\text { elbow into extension) }\end{array}$ \\
\hline
\end{tabular}

In all other regards the rules governing assignment of muscle grade would follow the conventions of the D\&W system. For example, an athlete with a hip contracture causing a flexion deficit of $40^{\circ}$ (i.e., an available range of $80^{\circ}$ hip flexion) but normal muscle strength in this range would receive a grade of 5 . 
Modification 4: Adjustment of movement assessment techniques

Some adjustments to testing methods - both patient positioning and stabilization techniques - may be required. For example, to assess hip flexion strength using the break test at $90^{\circ}$ (as proposed in Modification 3), it would not be possible to use the published
D\&W technique, which positions the person in sitting with the hip supported at $90^{\circ}$ flexion by the surface of the bench. Instead, the person should be positioned in standing, starting at $0^{0}$ hip flexion and move to $90^{\circ}$ flexion.

Table 3: Comparison of normal anatomical range of movement (ROM) and the maximum ROM required for running

\begin{tabular}{lcc}
\hline \multicolumn{1}{c}{ Movement } & $\begin{array}{c}\text { Anatomical ROM } \\
\text { (H. J. Hislop \& } \\
\text { Montgomery, 2002) }\end{array}$ & $\begin{array}{c}\text { Maximum ROM used in } \\
\text { running (Mann \& Hagy, } \\
\text { 1980; Novacheck, 1998) }\end{array}$ \\
\hline Hip Flexion & $120^{0}$ & $90^{0}$ \\
Hip Extension & $20^{0}$ & $5^{0}$ \\
Hip Abduction & $45^{0}$ & $5^{0}$ \\
Hip Adduction & $20^{0}$ & $5^{0}$ \\
Knee Flexion & $135^{0}$ & $120^{0}$ \\
Knee Extension & $0^{0}$ & $-15^{0}$ \\
Ankle dorsiflexion & $20^{0}$ & $10^{0}$ \\
Ankle plantar flexion & $45^{0}$ & $25^{0}$ \\
\hline
\end{tabular}

*In running the knee does not fully extend

\section{CONCLUSION}

In classification systems that assess impaired muscle strength, specification of the MMT methods used is an important means of minimizing potential sources of variation. The D\&W and MRC methods are both currently employed in Paralympic sports classification systems. Because the guidelines for administration of D\&W methods are more detailed and comprehensive, their use is likely to enhance the reliability of the classification process and therefore they should be preferred. To improve the validity, reliability and utility of the D\&W methods in a given Paralympic sports classification system, they should be modified in four ways, these being: 1) limiting assessment to those movements that are important to performance in the sport concerned; 2) specifying a single preferred technique for assessment of movement strength; 3) changing the reference range of

movement from normal anatomical range to the maximum range of movement required for the sport concerned; and 4) adjusting testing techniques so that they are relevant for the sport. Although the four areas of modification have been written specifically for the D\&W methods, the principles underpinning them can inform the modification of other published MMT methods to improve their suitability for sports classification.

\section{Acknowledgements}

Sean Tweedy's work is supported by the Motor Accident Insurance Commission (MAIC), Australia. Work for this paper was supported through funding from the Australian Research Council (LP0882187), the International Paralympic Committee, the Australian Paralympic Committee and the Australian Sports Commission.

\section{REFERENCES}

Clarkson, H. M. (2000). Musculoskeletal assessment: joint range of motion and manual muscle strength (2nd ed.). Philadelphia: Lippincott Williams \& Wilkins.

Cutter, N. C., \& Kevorkian, C. G. (1999). Handbook of manual muscle testing. New 
York: McGraw-Hill Health Professions Division.

Daniels, L., Worthingham, C. (1986). Muscle Testing Technique of Manual Examination (5th ed.). Philadelphia: WB Saunders Co.

Escolar, D. M., Henricson, E. K., Mayhew, J., Florence, J., Leshner, R., Patel, K. M., et al. (2001). Clinical evaluator reliability for quantitative and manual muscle testing measures of strength in children. Muscle Nerve, 24(6), 787-793.

Florence, J., Pandya, S, King WM, Robison, JD, Baty, J, Miller, JP, et al. (1992). Intrarater reliability of manual muscle test (Medical Research Council Scale) Grades in Duchenne's muscular dystrophy. Physical Therapy, 72(2), 115-127.

Frese, E., Brown, M, Norton, BJ. (1987). Clinical reliability of manual muscle testing: middle trapezius and gluteus medius muscles. Physical Therapy, 67, 1072-1076.

Guarantors of Brain. (2000). Aids to the examination of the peripheral nervous system. (4th ed. ed.). Edinburgh: W.B. Saunders on behalf of the Guarantors of Brain,

Hislop, H., Montgomery, J. (2007). Daniels and Worthingham's Muscle testing. Techniques of Manual Examination $\left(8^{\text {th }}\right.$ ed). St Louis: Saunders Elsevier.

Hislop, H. J., \& Montgomery, J. (2002). Daniels and Worthingham's Muscle Testing: Techniques of Manual Examination (7th ed.). Philadelphia: W.B. Saunders Company.
Kendall, F. P. (2005). Muscles: testing and function with posture and pain (5th ed.). Baltimore, MD: Lippincott Williams \& Wilkins.

Lawson, A., \& Calderon, L. (1997). Interexaminer agreement for applied kinesiology manual muscle testing. Percept Mot Skills, 84(2), 539-546.

Mann, R. A., \& Hagy, J. (1980). Biomechanics of walking running and sprinting. The American Journal of Sports Medicine, 8(5), 345-350.

Novacheck, T. (1998). The biomechanics of running. Gait and Posture, 7, 77-95.

Tweedy, S.M. (2002). Taxonomic theory and the ICF: Foundations for a United Disability Athletics Classification. Adapted Physical Acitivity Quarterly, 19, 220-237.

Tweedy, S. M., \& Vanlandewijck, Y. C. (2010). International Paralympic Committee position stand-background and scientific principles of classification in Paralympic sport. Br J Sports Med.

World Health Organization. (2001). International classification of functioning, disability, and health. Geneva: Author.

Wright, W. (1912). Muscle training in the treatment of infantile paralysis. Boston Med. Surg. J., 167, 567-574.

Corresponding author's e-mail address: seant@hms.uq.edu.au 


\section{AUSWAHL UND MODIFIZIERUNG DER METHODEN MANUELLER MUSKELTESTS ZUR KLASSIFIZIERUNG IM PARALYMPISCHEN SPORT}

(Abstract)

Viele paralympische Sportarten verwenden unspezifische manuelle Muskeltest(MMT)Methoden zur Überprüfung der Einschränkung der Muskelkraft. Das stellt eine mögliche Quelle für Ungenauigkeiten bei der Klassifizierung dar und könnte dadurch ausgeschaltet werden, dass man ein einziges offizielles Set an MMT-Methoden angibt. Des Weiteren können vier Modifikationen die Validität, die Reliabilität und die Nützlichkeit der konventionellen MMT Methoden zur Klassifizierung erhöhen: 1) Einschränkung der Überprüfung auf Bewegungen, die für die Leistung in der betreffenden Sportart wesentlich sind; 2) Festlegung einer einzigen zu bevorzugenden Technik zur Überprüfung der Muskelkraft; 3) Änderung des Referenzbezugs für die Beweglichkeit von der anatomisch normalen Beweglichkeit zu einem maximalen, in dieser Sportart geforderten, Bewegungsumfang und 4) Anpassung der Testtechniken wie sie für den Sport relevant erscheinen. Dieser kurze Beitrag könnte die Klassifizierung in etablierten Sportarten verbessern und richtungsweisend sein für aufstrebende Sportarten, die ihr Klassifizierungssystem erst entwickeln.

SCHLÜSSELWÖRTER: Muskelkraft, Kraftmessung, Paralympischer Sport, Behinderung

\section{SELECTION ET MODIFICATION DES METHODES DE TESTING MUSCULAIRE MANUEL POUR LA CLASSIFICATION DU SPORT PARALYMPIQUE}

(Résumé)

De nombreux systèmes de classification au sein des sports Paralympiques utilisent des méthodes non spécifiques de testing musculaire manuel (TMM) afin d'évaluer la perte de force musculaire. Ceci favorise une variabilité dans le système de classification et pourrait être évitée en sélectionnant un ensemble défini de techniques de TMM. De plus, quatre modifications peuvent renforcer la validité, la fiabilité et l'utilité des méthodes conventionnelles de TMM pour la classification des sports Paralympiques : 1) limiter l'évaluation aux mouvements déterminants de la performance pour les sports concernés ; 2) évaluer la force musculaire d'une façon unique ; 3 ) remplacer la référence de valeur normale (anatomique) de plage maximale angulaire de mouvement par une plage angulaire spécifique au sport concerné ; et 4) adapter les techniques de testing musculaire manuel de manière à ce qu'elles deviennent appropriées au sport. Cette brève communication devrait aider à améliorer le système de classification pour les sports concernés et donner une direction à suivre pour les sports émergents qui utilisent un système de classification.

MOTS CLES : force musculaire, évaluation de la force musculaire, sports Paralympiques, handicap

\section{ВЫБОР И МОДИФИКАЦИЯ МЕТОДОВ МАНУАЛЬНО-МЫШЕЧНОГО ТЕСТИРОВАНИЯ ДЛЯ КЛАССИФИКАЦИИ В ПАРАОЛИМПИЙСКОМ СПОРТЕ}

(Аннотацця)

В Параолимпийском спорте существующие системы классификации используют неопределенные методы мануально-мышечного тестирования (ММТ) для оценки изменения мышечной силы. Это является потенциальным источником противоречий в классификации, который может быть устранен путем выявления единого, опубликовано множество ММТ методами. Кроме того, четыре модификации могут повысить достоверность, надежность и полезность общепринятых методов ММТ для классификации: 1) ограничение оценки 
движений, которые имеют важное значение для исполнения в определенном виде спорта; 2) установление единой методики оценки двигательной силы; 3) изменение соотношения диапазона движения от нормального анатомического до максимального, требуемого в спорте; и 4) настройка методов тестирования так, чтобы они были актуальны в сфере спорта. Это краткое сообщение может усовершенствовать классификацию в существующих видах спорта, и служить основой для новых видов спорта, которые развивают системы классификации.

КЛЮЧЕВЫЕ СЛОВА: мылечная сила, Паралимпийский спорт, инвалидность

\section{SELECCIÓN Y MODIFICACIÓN DE LOS MÉTODOS MANUALES DE EVALUACIÓN MUSCULAR PARA LA CLASIFICACIÓN EN DEPORTE PARALÍMPICO}

(Resumen)

Muchos deportes paralímpicos usan sistemas de clasificación no específicos, como el método manual muscular (MMT) para evaluar el deterioro de la fuerza muscular. Esta es una posible fuente de inconsistencia en la clasificación, y podría ser eliminado por ejemplo, publicando un conjunto de métodos sobre MMT. Además, cuatro modificaciones pueden mejorar la validez, fiabilidad y utilidad de los métodos convencionales de MMT para la clasificación: 1) limitando la evaluación a los movimientos que son importantes para el rendimiento en el deporte en cuestión, 2) especificando una sola técnica preferida para evaluación de la fuerza del movimiento, 3) cambiando el intervalo de referencia del movimiento desde el rango anatómico normal al rango máximo de movimiento requerido en el deporte, y 4) ajustando las técnicas de evaluación para que sean relevantes para el deporte en cuestión. Esta breve comunicación puede mejorar la clasificación en deportes establecidos, y proporcionar orientación para los nuevos deportes que están desarrollando sistemas de clasificación.

PALABRAS CLAVE: fuerza muscular, evaluación de la fuerza en Paralímpicos, deporte, discapacidad.

\section{SELECIONANDO E MODIFICANDO MÉTODOS DE AVALIAÇÃO MUSCULAR MANUAL PARA A CLASSIFICAÇÃO NO DESPORTO PARALIMPICO}

(Resumo)

Muitos dos sistemas de classificação no desporto paralímpico utilizam métodos de avaliação muscular manual (AMM) não específicos para avaliar as limitações em termos de força muscular. Esta é uma fonte potencial de inconsistência ao nível da classificação, a qual poderá ser eliminada através da publicação de um conjunto único de métodos de AMM. Adicionalmente, existem quarto modificações que podem contribuir para a melhoria da validade, da fidedignidade e da utilidade dos métodos convencionais de AMM para a classificação: 1) limitar a avaliação a movimentos tidos como importantes para a performance em cada um dos desportos; 2) especificação de uma única técnica preferencial de avaliação da força em determinado movimento; 3) modificar a referência da amplitude do movimento da amplitude anatómica normal para a amplitude máxima do movimento necessária no desporto, e 4) ajustar as técnicas de avaliação para que elas sejam relevantes para o desporto. Esta breve comunicação poderá contribuir para a melhoria da classificação nos diferentes desportos, e proporcionar importante orientação para desportos mais recentes que estão a desenvolver os seus sistemas de classificação.

Palavras-chave: Força muscular, avaliação paralímpica da força, desporto, deficiência 